\title{
The Role of Homegarden Agroforestry in Househld Livelihoods at Yayo Coffee Forest Biosphere Reserve, Chora District, Southwestern Ethiopia
}

\author{
Gemeda Terfassa Fida MSc \\ Department of Natural Resources Management, Jimma University, Ethiopia
}

\begin{abstract}
Traditional homegardens in southwest Ethiopia is well-known land use practices playing an important role in livelihood aspects. Thus, the objective of this study was to examine the contribution of homegardens towards of local people livelihoods. A household interview data collection method was used. A systematic random sampling method was used to select 139 households. Descriptive statistics, one way ANOVA were used for analysis. Homegarden agroforestry was more important for a food source, and contribute about 4079.70Birr annual income on average. This study suggests that homegardens contribute to the sustenance of the livelihoods of smallholder farmers in the study area.
\end{abstract}

Keywords: Yayo, Coffee Forest, Buffer Zone, Cash Crop, Food Security

DOI: $10.7176 / \mathrm{JBAH} / 11-21-01$

Publication date: November $30^{\text {th }} 2021$

\section{INTRODUCTION}

\subsection{Background and Justification}

Agroforestry is a dynamic land use practices that maintain overall farm productivity by combining herbaceous food crops with woody perennial and livestock on the same piece of land. Homegardens are among agroforestry practices with the most complex and diverse agroecosystem that have been developed by numerous human cultures worldwide. They played an important role towards the development of early agriculture and domestication of crops. Homegardens often show a promising option for biodiversity conservation and mitigation of ecosystem degradation. In some cases, they were found to be equally effective as natural forests in the conservation of tree species diversity (Abdoellah et al., 2006; Mohri et al., 2013; Jhariya et al., 2015).

Homegardens as an ecosystem contain multiple levels of diversity, including cultural, genetic and agronomic diversity. The high diversity of species in homegardens, which combines crops, trees and animals have different uses and production cycles is considered as an essential component of sustainable agriculture because of the wide socioeconomic and ecological roles it plays in these systems. Studies carried out in homegardens of various regions have recorded notable richness of species and varieties that provide an additional food supply and cash income for the people. They have been playing essential socioeconomic and ecological role due to the fact that it is related to the production of food and other products such as the source of firewood, fodder, medicinal plants, cash crops, and ornamentals (Das and Das 2005; Bharucha and Pretty, 2010; Olango et al., 2014).

In relation to conservation of biodiversity, Galluzzi et al. (2010), describes that homegardens are taken as key places for conserving plant biodiversity. It is exhibited that homegardens are serving as refugees camp for a number of plants species especially for those plant species that are not widely grown in the larger agroecosystem. They are microenvironments containing high levels of species and genetic diversity which serves not only as sources of food, fodder, fuel, medicines, spices, construction materials and income in many countries around the world, but are also important for in-situ conservation of a wide range of plant genetic resources. However, homegardens structure, composition, and species and cultivar diversity are influenced by changes in the socioeconomic circumstances and cultural values of the households that maintain these gardens (Emmett and Nye, 2017).

Integrating multipurpose trees with food crops and livestock in homegardens in the intimate association is an ancient activity in Ethiopia (Anjulo and Mezgebu, 2016). According to Berhanu and Asfaw (2014), Ethiopian homegardens as an ecosystem encompass multiple levels of diversity, including cultural, genetic and agronomic diversity. About 539 species belonging to 352 genera and 109 families were recorded in Ethiopian homegardens which make up nearly $9 \%$ of the Ethiopian higher flora, were reported. Conversely, the recent transition of the homegardens into commercial production of new cash crops, including khat (Catha edulis) is a farming strategy undertaken by smallholders to address demographic, market and socioeconomic changes in the country. The changing socioeconomic conditions and advent of commercial forces have introduced the concept of cash with homegardens (Bargali et al., 2015; Gebrehiwot et al., 2016).

On the other hand, the ongoing land fragmentation and the declining farm size in rural Ethiopia have limited the livelihood choices and opportunities of most smallholder farmers. The expansion of cultivated area is 
likely to require further infrastructure development that would result in further negative environmental implications with huge loss of biological diversity. In order to adapt to such socioeconomic changes, subsistence-oriented agroforestry homegardens are increasingly becoming more commercially oriented. This ongoing land use change has been carried out at the expense of diversity and stability of the long-existing farming practices important for sustainable livelihoods and food security (Gole et al., 2009; Seyoum et al., 2012; Mohri et al., 2013; Gebrehiwot et al., 2016).

In addition, reduction of forest resources and increasing demand for its products especially in areas where people rely on natural resources for their livelihood needs are common. Finding alternative options to this widened gap between the demand and supply of forest products for local livelihood sustenance coupled with the natural resources conservation goal attainment is a fundamental concern. Homegarden seems to have the potential to provide options for sustained rural livelihoods and biodiversity conservation. It integrates protected areas with the surrounding landscapes and mediates the livelihood need of people within the conservation goal of the protected area. Thus it provides a potential to reduce land-use pressure and improve rural livelihoods in human-dominated landscapes and at the same time conserving a large proportion of biodiversity (Jose, 2012).

Although extensive areas of traditional agroforestry homegarden exist in southwestern Ethiopia, the locals' priorities to satisfy the immediate needs for food and cash under socioeconomic changes are being carried out at the expense of the diversity and stability of existing land use systems in the area (Abebe, 2005; Abebe et al., 2010). According to Kassa et al. (2012), the conversion of natural forest to monoculture in the area results in significant impacts on biodiversity richness of homegarden.

Moreover, following the nomination of Yayo Coffee Forest Biosphere Reserve (YCFBR), as a site for biodiversity conservation in southwestern Ethiopia (Goleet al., 2009), the local people dependency on homegarden as an alternative option is increasing. However, less emphasis is given towards of assessing existing plant diversity in homegarden, particularly in Chora district. The homegardens potential for conservation of biological diversity and economic returns are not fully studied. Thus, there is no inventoried documentation about structure, composition and plant diversity for the district.

According to Agbogidi and Adolor (2014), to determine how homegardens can best contribute to conservation, it is necessary to understand what diversity is being maintained by farmers. Hence, in order to strengthen and make the existing practice effective for plant diversity conservation and thereby to meet the homegarden products for locals need, scientific information is required. The study has a vital role for natural resources conservation and local people livelihood sustenance; it documents the role of homegarden towards of plant biodiversity conservation by describing floristic richness and diversity of the practice. It also describes their role to communities' livelihood, food security and income generation at the household level.

\subsection{Objective of the Study}

To investigate homegardens role to households livelihood

\subsection{Research Questions}

The study was aimed to address the following research question:

What is the role of homegarden to the households' livelihood in the study area?

\section{REVIEW OF LITERATURES}

\subsection{Homegarden Agroforestry}

Homegarden refers to the deliberate management of multipurpose trees and shrubs (the woody component) grown in intimate association with herbaceous species (mainly annual, perennial, and seasonal agricultural crops) and invariably livestock within the compounds of individual houses the whole crop-tree-animal unit being intensively managed by family labor). It is an integrated system which comprises different things in its small area that produces a variety of foods and agricultural products including staple crops, vegetables, fruits, medicinal plants and so on (Panwar and Kaushal, 2017).

Homegarden agroforestry is an age-old and time-tested land use approach that makes the best use of nature's goods and services. These homegardens are evolved either through growing food crops in the forests or establishing tree crop production systems on arable lands. Furthermore, the homegarden agroforestry reflects the wisdom of the traditional culture and ecological knowledge of the local community. Most of the homegardens form a rich biodiversity source having several types of diversity, including cultural, genetic and agro-economic diversity (Lambin and Meyfroidt, 2011).

Homegardens are intensively cultivated agroforestry systems managed within the compounds of individual homes having diversity on the basis of local conditions. They comprise of a wide variety of productive trees, shrubs, vegetables, medicinal plants, herbs, fodder, and sometimes even staples and provide both economic and social benefits that are essential to the nutritional welfare and security of the household. These gardens, with their diversified agricultural crops and trees, fulfill the basic needs of the local population. Growing and 
maintaining plant species in the vicinity of home and making their products by household members were primarily intended for the family consumption. They are one of the best known traditional practices for livelihood, and sustainable development (Kittur and Bargali, 2013; Bargali et al.,2015; Parihaar et al.,2015).

Homegarden is a sustainable multiple-production system whose outputs can be adjusted to local needs. While the multistoried arrangement and high species diversity of the homegardens help to reduce environmental deterioration commonly associated with monocultural production systems. Moreover, it can be regarded as an informal plant introduction and distribution centers. Homegardens are commonly defined as a piece of land with a definite boundary surrounding a homestead, being cultivated with a diverse mixture of perennial and annual plant species, arranged in a multilayered vertical structure, often in combination with raising livestock, and managed mainly by household members for subsistence production (Kebede, 2010).

Homegardens appeared to have developed in the Indian subcontinent, Indonesia, Philippines, Malaysia, SriLanka and other parts of Southeast Asia, the tropical Pacific island, the Caribbean and various parts of tropical Latin America and Africa and can be found in almost all tropical-subtropical ecozones where subsistence land use systems predominate. The presence of homegardens in the highlands of Ethiopia (eastern Sidama highlands, enset, and cereals around Amhara settlements) similar to other tropical nations and they collectively house a large diversity of plant types that range from staple food crops to ornamental plants (Nayar, 2010; Jaganmohan et al., 2012; Haile, 2017).

\subsubsection{Structure and composition of homegardens}

Lope-Alzina and Howard (2012), report that tropical homegardens consist of an assemblage of plants which may include trees, Shrubs, vines and herbaceous plants growing in or adjacent to a homestead or home compound. Okafor and Fernandes reported that in this system, multipurpose trees and Shrubs in a multistory association with agricultural crops are raised with livestock in the homestead. In agroforestry, it implies the intimate association of multipurpose trees and Shrubs with annuals and perennial crops and invariably livestock within the compound of individuals with the whole crop-tree-animal- the unit being managed by family labor.

Bijalwan (2012), also studied structure, composition, and diversity of fruit trees and shrub species in mid hill situation of Garhwal Himalaya (between 1000 to $2000 \mathrm{~m}$ asl), India, covering winter and summer season. This was also an aspect based study included the northern and southern aspects of the study area. A total of 12 fruit tree species ( 4 trees were common in northern and southern aspect and 6 trees were only noticed in northern aspect while 2 in the southern) were recorded in an agri-horticulture system with apple tree (Malus domestica) was a dominant fruit tree in both the aspects. A remarkable high agricultural crop diversity was also from the northern aspect in both the seasons.

Almost all homegardens have the most visible characteristics such as layered canopy and harmonious admixture of species, and specific place and functions but the main difference are seen in homegarden size, shape, and intensity of cultivation, the types of crops grown and complexity of species diversity. In general terms, all homegardens consist of three main layers, of this herbaceous layer near the ground, a tree layer at upper levels, and intermediate layers in between. The lower layer can usually be partitioned into two, with the lowermost (less than $1 \mathrm{~m}$ height) dominated by different vegetable and medicinal plants, and the second layer (1 $3 \mathrm{~m}$ height) being composed of food plants such as cassava, banana, yam, and so on (Ajah, 2013; Sinku, 2016).

Zaman et al. (2010), conducted a study to assess the composition, structure, diversity of plant species and contribution of homegarden to household food security, conservation of plant species, socio-economic importance and the constraints of the total production system in Thakurgaon district of Northern Bangladesh. They stated that the homegarden size in average in the study area increased with the size of total land holding and total income was found higher in large farm category than that of marginal. They also recorded 37 useful plant species and mentioned the diversity and abundance of fruit tree species were higher in all farm categories followed by timber and fuelwood species. Mango and jackfruit were identified as an important cash-growing crop in the study area. Tree management practices and the scopes were very common but the farmer faced many problems during tree plantation including the animal and insect problems.

The compositions of crops grown in homegardens can be grouped based on function as ornamental, fruits, food crops, vegetables, medicinal, spices and fodder, building materials and fuelwoods. The patterns and compositions of homegardens are disordered due to the educational level of gardener, the indigenous knowledge of farmer, the market and the size of land availability. Thus, several patterns of homegarden have no particular patterns also sociocultural, environmental and ecological factors determine species composition and types of homegardens. Plant compositions in Ethiopian homegardens are grouped under the three main types of garden crops, live fence species, useful wild and semi-wild plants (Asfaw; 2001; Acheampong et al., 2012).

Depending on the cultural factors, the size, shape and plant diversity of homegardens also vary across the globe. Homegardens in Ethiopia have variable shapes: some almost encircle the house others square, rectangle or irregular. Patterning of the crop also varies from place to place. For instance, the plants like bamboos are on the outer margins, some are planted inside margin next to the fence, chat, coffee, and enset are planted in the depressions of rows, others like perennial planted far apart with water collection depressions. Gardens usually 
have boundaries from home of other homegardens by fences; dry woody material, stones, and live plants (thorny shrubs) and sometime bounded by natural barriers like rivers, gorges (Tshiguvho, 2008; Goddard et al., 2010).

\subsubsection{Identification feature of homegardens}

According to Calvet et al. (2016), homegardens are identified by five characteristics. First; the garden is located near the residence. Second, the garden contains a high diversity of plants. To these criteria, some add that the garden recycles nutrients in a sustainable manner that plants are planted densely, and that plants are layered to mimic natural forest. Third, garden production is additional rather than a main source of family consumption or income. Fourth, the garden occupies a "small" area. A fifth distinguishing characteristic of homegardens that offered by is that homegardens are a production system that the poor can easily enter at some level since it may be done with practically no economic resources, using locally available planting materials, natural manures and indigenous methods of pest control.

In the tropics, two types of homegardens are recognized based on their contribution to the benefits of households. The first types are small-scale supplementary food production systems around the house in areas where the subsistence of the owners is based on their land use. The Java monoculture rice production and homegardens in Latin America belong to this category. The second types of homegardens stretched from fields around the house that constitute the most important means of the livelihood for farming households. Most of the homegardens in the highlands of eastern Africa belong to this type. It is also a place for experiments and even fundamental research and the groundbreaking genetic research. Homegardens are also subdivided into two basic types as city or urban, and the Kebele or rural homegardens (Barthel and Isendahl, 2013; Kitalyi, 2013).

\subsection{The Concepts of Livelihood}

A livelihood comprises the capabilities, assets (including both material and social resources) and activities required for a means of living (Table 1). It is the set of capability, assets, and activities that furnish the means for people to meet their basic needs and support their well-being. Livelihood is not simple phenomena for local people rather it is connected with the environment, economic, political and cultural processes to wider regional, national and global area. A livelihood is sustainable when it can cope with and recover from stress and shocks and maintain or enhance its capabilities and assets both now and in the future, while not undermining the natural resource base (Chambers and Conway, 1992; Schumacher, 2011).

The concept of livelihood is increasingly becoming central in the debate of rural development, poverty reduction, and natural resources management. Livelihood analysis has gone beyond the narrow definition and approach to poverty reduction. It had been narrow because it was focused on a certain aspect or implication of poverty such as low income and did not consider another vital aspect like shock and social factors. It is well recognized, that factors and conditions which constrain or enhance people ability to make a living needs emphasis around social, economic, and environmental aspects. In this regard, a livelihood concept is comprehensive and central. The livelihood framework helps in the analysis of a particular context (policy, history, agro-ecology, and socioeconomic situations), a mix of livelihood resources (capitals) result in the ability to follow what combination of livelihood strategies with what outcome. A livelihood is sustainable according to Ian Scoones 'when it can cope up with and recover from stress and shocks maintain or enhance its capabilities and assets, while not undermining the natural resource base (Scoones, 1998) "

The objective of achieving sustainable livelihoods for everyone provides a focus for anticipating the $21^{\text {st }}$ century through implications of policies and interventions that enhance capabilities, equity, and increase social sustainability for improving the livelihoods of the poor. Providing access to resource-based opportunities should be the minimum of state-provided social services and livelihood security of pro-poor intervention (Chambers and Conway, 1991).

Table 1: Assets or capitals of sustainable livelihoods

\begin{tabular}{|c|c|c|}
\hline No. & Asset & Description \\
\hline 1 & Natural assets & $\begin{array}{l}\text { Represent natural resources such as land, water and wider } \\
\text { environmental goods that are critical for the rural livelihoods; }\end{array}$ \\
\hline 2 & Social assets & $\begin{array}{l}\text { Refer to the institutions, relationships, and norms that shape the } \\
\text { quality and quantity of social interaction; }\end{array}$ \\
\hline 3 & Economic/financial assets & $\begin{array}{l}\text { Denotes the financial resources that people use to achieve their } \\
\text { livelihood objectives: incomes, profits, savings, and credits; }\end{array}$ \\
\hline 4 & Human assets & $\begin{array}{l}\text { Representing the skills, knowledge, experience, ability to work } \\
\text { and good health that together enable people to pursue their } \\
\text { livelihood strategies; and }\end{array}$ \\
\hline 5 & Physical assets & $\begin{array}{l}\text { Denotes asset Such as transport, shelter, road, market, adequate } \\
\text { drainage facilities, electricity and telecommunications }\end{array}$ \\
\hline
\end{tabular}

Source: Adopted from (Morse et al., 2009; Kaushal and Kala 2014). 


\subsection{Socioeconomic aspects of owners of homegarden}

Mercer and Miller (1998), conducted a quantitative and qualitative analysis of published socioeconomic research papers and a survey of agroforestry socioeconomic researchers are used to evaluate the achievements over the past 14 years. Their study focused on the major advances, gaps in knowledge, and constraints for closing those knowledge gaps etc. They observed that both the scope and the quality of socioeconomic research are slowly improving. They suggested the priority areas for future research include theoretical and empirical analyses of agroforestry adoption decisions, improved economic analyses, and policy studies at local, national, and regional levels.

Kabir and Webb (2009), examined whether a household's socio-economic attributes had a quantitative and predictable relationship with homegardens. They analyzed the floral structure of randomly selected 402 homesteads of Southwestern Bangladesh. They reveal the importance of homegardens in job creation and women empowerment. Active participation of women in homegardening reduced gender inequalities in the family. However, increasing population density and the concomitant fragmentation of landholdings to homesteads may create an opportunity for homegarden promotion in Bangladesh.

John and Nair (1999), examined the socio-economic factors and constraints that affect farming in 400 homegardens of Southern Kerala, India. The found that the cattle $(17.5 \%)$ and poultry $(30.25 \%)$ raising as an important complementary enterprise. An average of 14-15 species and 397 plants per homestead was observed. These include coconut, rubber, spices, vegetable, timber, tuber crops, fruits, fuel trees, and fodder. Cultivation cost, labor availability, credit availability and technical information availability, availability of manures and fertilizers, availability of plant protection chemicals, marketing facilities, and storage facilities were considered as major constraints in the homegarden.

Puri and Nair (2004), evaluated benefits of various tangible and intangible benefits (social, cultural and economic benefits) of agroforestry but they didn't mention about the socioeconomic elements and their significance in the determination of success and failure of agroforestry. But some success tales such as wasteland reclamation and poplar-based agroforestry have shown that the technologies are widely adopted when their scientific principles are understood and socio-economic benefits are convincing.

\subsection{Homegarden Contribution to households}

Agroforestry homegardens plays a vital role in contributing to peoples livelihoods. Maroyi (2009) and Acheampong et al. (2011), reported that Agroforestry homegardens improve the family's nutritional status, health, and food security. Agroforestry homegardens, therefore, is part of a household livelihood strategy and has gained prominence as a natural asset through which sustainable use of resources, particularly for the livelihoods of the poor, may be achieved. Homestead gardening and Agroforestry systems provide an important contribution to sustainable agricultural production because of their potential to meet economic, social, ecological, and institutional conditions for sustainable livelihoods (Nair, 2006).

Homegarden plays an important role in sustainable livelihood needs of the household members. Brownrigg (1985), reported that in many parts of the world homegarden systems provide supplementary food, fuel, fodder and serve as a recovery area for the people such as homegardens in northeastern Brazil contributed to the sustainable use of natural resources by reducing pressure on the native vegetation ((Trinh et al., 2003; Albuquerque et al., 2005).

Tesfaye (2013) reported that supporting the potential of population densities of over 500 persons/ $\mathrm{km}^{2}$ in the areas of southern Ethiopia and the rich species diversity shows its importance for simultaneous and combined biodiversity conservation, livelihood, and food security. Thus, agroforestry homegardens are used to produce all livelihood assets that generate and deliver multiple benefits for the livelihood of the rural people. Agricultural land as a natural asset is the primary means of enhancing and improving livelihoods for the overwhelming majority of the rural population.

\subsubsection{Contribution of homegardens to household food security}

Tynsong and Tiwari (2010), stated that the homegardens contribute a great deal to food supply especially for the people living in the rural areas because of the high production and diversity of cultivated edible species. Although the extent of household dependency on homegardens varies considerably, its contribution is quite significant towards the livelihood of the people because of low investment and easy accessibility. Homegardens function as ex-situ as well as in-situ conservation plots for plant genetic resources of the region. In the villages studied, 103 wild plant species were recorded from the homegardens which showed that homegardens are also a home to many wild plant species, thus they serve as a repository of wild plants.

In most tropical agroforestry homegardens, food production is the first function and role. One major aspect of the significant role of food production in homegardens is to hold up continuous production throughout the year (Kebebew et al., 2011), reported that in Southern Ethiopia 88.8\% of the surveyed households were food secured throughout the year. Homegardens also can solve the problem of land scarcity by using a small land the households have by integrating various components in the same piece of land hence food security and income 
generation (Abebe, 2005).

The combination of crops with different production cycles and rhythms results in a relatively uninterrupted supply of food products. Depending upon the climate and other environmental characteristics, there may be peak and slack seasons for harvesting the various products, but generally, there is something to harvest daily from most homegardens. Additionally, these harvesting and maintenance operations require only a relatively small amount of labor from the members of the family. Hence homegardens are among the best solutions for household food security and income generation to smallholder farmers due to their diversity. This is especially in all areas of the tropics under pressure from increasing populations and unsystematic deforestation (Nair and Kumar, 2004; Kebebew et al., 2011; Lulandala, 2011).

\subsubsection{Homegardens to income generation}

Homegardens can contribute to household income in several ways. Income from homegardens comes from selling cereal crops, fruits, vegetables, and other cash crops (e.g., lime, rambutan, jackfruits, durian, cloves, and coffee) to local brokers or merchants. In many cases, sales of products produced in homegardens significantly improve the family's financial status. In Indonesia and Nicaragua homegardens contributed $21.1 \%$ and $35 \%$ of their total income respectively. In South-West Bangladesh and North Eastern Bangladesh, an average of 15.9\% and $11.8 \%$ of household income is derived from homegardens respectively. Hence generally, homegardens play a great role in income generation as compared with other sources as it uses multiple components that produce diverse products (Motiur et al., 2006; Tynsong and Tiwari, 2010).

\subsection{The Biosphere Reserve Concept}

Biosphere Reserves (BRs) are "areas of terrestrial and coastal/marine ecosystems or a combination, which are internationally recognized within the framework of UNESCO's programme on MaB". The BR concept, as the pillar of MaB conservation work, was developed in 1974 to encourage the establishment of protected areas and also to address the need to balance conservation of biological and cultural diversity with economic and social development. UNESCO BRs are currently served as "living laboratories for sustainable development" and are "the only sites under the United Nations system that calls for conservation and sustainable development to proceed along mutually supportive paths" (UNESCO 2010; Coetzer et al. 2013).

The biosphere reserve is a unique kind of protected area registered by UNESCO BRs with three main functions that are interdependent and equally important: Conservation of genetic resources, species and ecosystems, scientific research and monitoring; and promoting sustainable development (Jerneck and Olsson, 2013). UNESCO BRs have three clearly defined zonations; (Core area, buffer zone, and transition zone). The "core area" is strictly protected in a legal sense. It is typically small in comparison to entire biosphere reserve; of all human activity typically only research is allowed there. The' 'buffer' zone surrounds the core area, with some restrictions as well human activity in this area should be compatible with conservation goals. In the transition area, the focus is not restrictions, but the promotion of sustainable practices (Beery et al., 2015).

YCFBR is one of the Ethiopian BRs that have been registered as UNESCO Man and Biosphere (MaB) reserves in June 2010. Parts of the YCFBR were declared a National Forest Priority Area and gene reserve in 1998, and the whole zone was declared a United Nations Educational, Scientific and Cultural Organization (UNESCO) biosphere reserve in 2010. It is one of the biodiversity hotspots in Ethiopia. The YCFBR covers 167,021 ha, with the most important landscapes being forest, agricultural land, wetland, and grazing land (Table 2).

Yayo forests belong to the eastern Afromontane type and identified as one of the 34 biodiversity hotspot areas in the world by Conservation International. YCFBR is one of the habitats for a diversity of Coffee arabica and hence is important for in-situ conservation of the genetic diversity of the natural coffee. Coffee alone contributes around $70 \%$ of households' income in the area (Gole et al., 2009; Woldegeorgis and Wube, 2012; ECFF, 2016).

Table 2: Areas of Yayo Coffee Biosphere Reserve

\begin{tabular}{|c|c|c|c|c|}
\hline \multirow[t]{4}{*}{ YCBR } & Total Area (ha) & Biosphere Zones & Area (ha) & Area (\%) \\
\hline & & Transitional & 117,736 & 70.5 \\
\hline & 167,021 & Buffer zone & 21,552 & 12.9 \\
\hline & & Core zone & 27,733 & 16.6 \\
\hline
\end{tabular}

Source: Adopted from ECFF (Environment and Coffee Forest Forum, 2017).

\section{MATERIALS AND METHOD}

\subsection{Description of the Study Area}

\subsubsection{Yayo coffee biosphere reserve (YCFBR)}

The study area YCFBR is located in the Oromiya state, south-western Ethiopia,between $8^{\circ} 10^{\prime}-8^{\circ} 39^{\prime} \mathrm{N}$ and $35^{\circ} 30^{\prime}-36^{\circ} 4^{\prime}$ E. The area was registered in 2011 by the UNESCO as the 'Yayo Coffee Forest Biosphere 
Reserve' for the in-situ conservation of wild Coffea arabica. It covers about 167,021 ha split into six woreda 1 , namely Algae Sachi, Bilo-Nopa, Chora, Doreni, Hurumu, and Yayo (Gole et al., 2009). The area has a rolling topography where altitudes range from 1140 to $2562 \mathrm{~m}$ a.s.1., and is crossed by three major rivers, i.e., Geba, Dogi and Sese. The climate is hot and humid, and the mean annual temperature is around $20^{\circ} \mathrm{C}$ oscillating between the average extremes of $12{ }^{\circ} \mathrm{C}$ and $29^{\circ} \mathrm{C}$. The area exhibits a uni-modal rainfall pattern with mean annual precipitation of $2100 \mathrm{~mm}$, with high disparity from year to year, and ranging from 1400to $3000 \mathrm{~mm}$ (Gole et al., 2008). Dominant soil groups include nitosols, acrisols, vertisols, and cambisols (Senbeta et al., 2005).The reserve is managed in zones, so that smallholder farmers can still use forest resources sustainably. The core zone encompasses 27,733 ha of undisturbed natural forest; the buffer zone 21,552 ha of mostly semi-coffee forest, where restricted use of forest resources is allowed (Schmitt et al., 2010). The research was conducted in the YCFBR areas (specifically in Hawayember, Sololo and Uta None kebeles of Chora district (Figure 1).

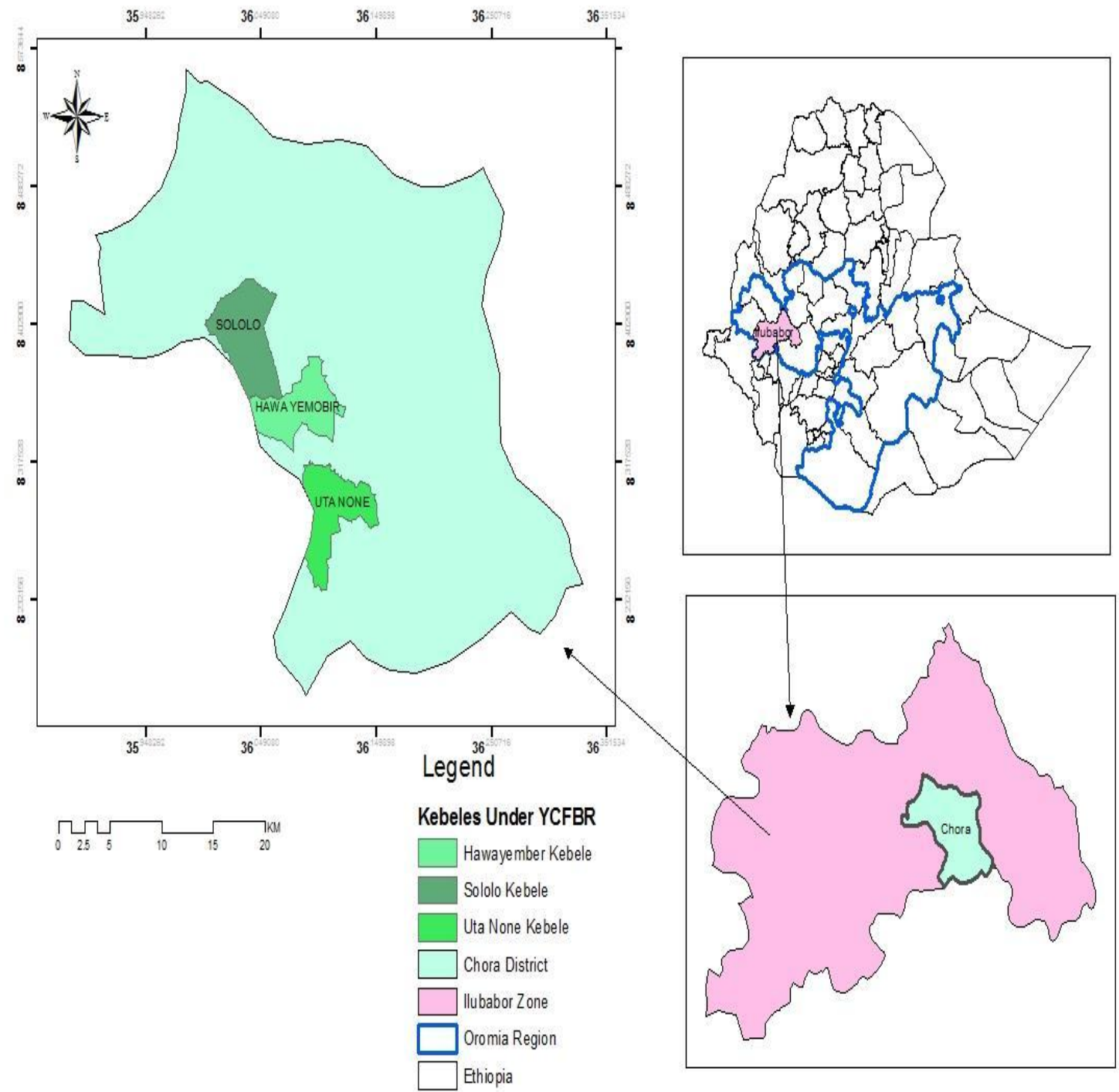

Figure 1 : Map of the study area

\subsubsection{Population}

In 2007, around 310,000 people lived in the six woreda (CSA, 2007). The Oromo ethnic group predominates and is considered indigenous. There are a significant number of Amhara, Tigreway and Kembata as they migrated from other parts of the country due to the government's forced resettlement program of 1984 (Kassaet al., 2009). Orthodox christian, muslim, protestant and indigenous beliefs are evenly practiced (Tulu, 2010). Currently, the population of Yayo is booming due to the high birth rate, and the intense internal migration due mainly to the thriving infrastructural development (Tadesse, 2015), such as the construction of fertilizer and coal factories, a network of roads planned to ease the trade of coffee, and the forthcoming hydroelectric dam on the Geba River (Bacha, 2014). 


\subsubsection{Land use systems}

The major land-use types are forest, agricultural land, wetland, and grazing land (Figure 2). Forests cover most of the area, and consist of four major variations, namely undisturbed natural forest, semi-forest coffee systems, fully managed forest for coffee production, and old secondary forests (Gole et al., 2009).

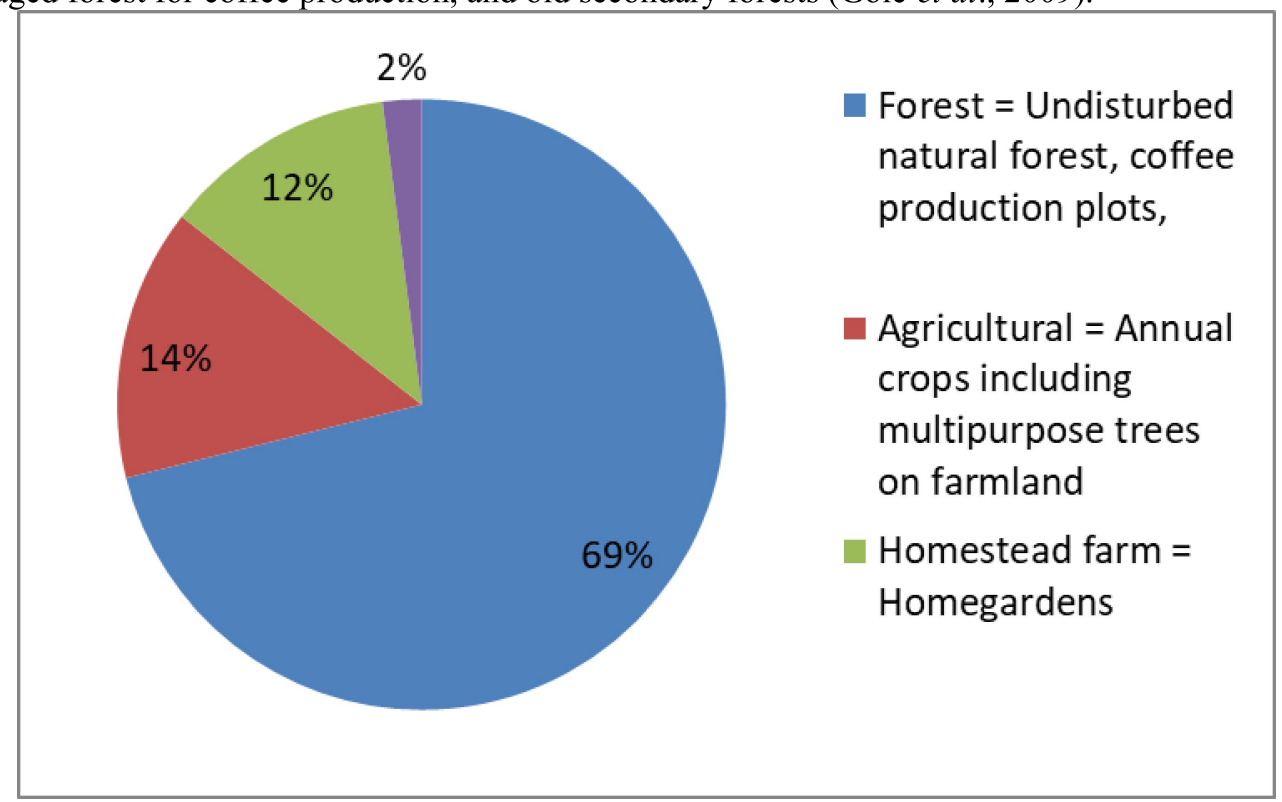

Figure 2: Major land-use type in YCFBR area (\%) adapted from Assefa, (2010)

\subsubsection{Transitional zone of YCFBR and households livelihood}

The transition area is found adjacent to the buffer zone and it is composed of agricultural land, wetland, grassland, settlement area and fragments of forest land and covers area of 117,736 ha. It is the place of residence for all the human population in the biosphere reserve, the development organizations and local institutions. Around 154,300 permanent residents live in the transition areas of the Biosphere, including urban and rural settlements of whom the majority depend on agriculture for their livelihoods. Most income for the livelihood of the population of the area comes from the transition area(UNESCO 2010; Teketay et al., 2010).

The main livelihood source of the Yayo households is coffee-based agriculture, which employs over $90 \%$ of the active labour of the area (Assefa, 2010). Most coffee plots are small, however it is estimated that more than $60 \%$ of the population depends on coffee production and coffee-related activities, such as collection, processing and marketing (Gole, 2003; Ilfata, 2008). Besides coffee and the other cash crop khat, smallholders produce annual crops, such as Zea mays, sorghum (Sorghumbicolor), teff (Eragrostis teff), and other cereals and pulses.

Farmers in the transitional zone own and cultivate land and are free to use it as they like. Many of them also own patches of private coffee forest in the transitional zone and have been assigned patches in the buffer zone.The agricultural landscape of the transition zone includes some of the semi-forest coffee production areas, garden coffee, small coffee plantations, cropland, and grazing land. Even though the area has abundant resources, which can support the local livelihood and the quality of important products like coffee, honey and spices, it has a large potential for improvement, mainly due to lack of improved production and processing technologies. The transition part of YCFBR has a lot of spices and herbs flora; among Korarima (Aframomum korarima) spice ranks first and other spices such as chilies, ginger, turmeric, coriander, etc. are grown widely (Etissaet al., 2016).

The agricultural landscape of smallholder surrounding the forest area is also important for the conservation of cultivated many horticultural crop landraces. The smallholder farmers in the this area grow cereals, legumes, coffee, vegetables, fruits, root and tubers, spices and herbs and other crops together either as sole crop or in a combinations others in the homegardens with the shade trees (Tadesse et al., 2009) as cited in (Etissa et al., 2016).

YCFBRarea is forest environment, its arabica species, and makes a meaningful contribution to the livelihoods of hundreds of smallholder farmers (Bharucha and Pretty, 2010). Also, according to Kuria et al. (2016), the farmers cultivate diverse crops in YCFBR areas. They do not solely rely on one cereal but many households cultivate a mix of two to four different staple items such as maize, sorghum, millet, wheat, barley and teff(Eragrostis teff).

In addition they grow different pulses (beans, peas, and chickpeas), root and tuber crops (potato, sweet potato, beetroot, carrot, anchote and enset (Ensete venricosum), vegetables (hot/green pepper, tomato, pumpkin, Ethiopian kale, cabbage, Tarro, Abrango, onion and garlic), fruits (avocado, banana, mango, papaya, orange, lemon, and jackfruit) and a variety of spices (ginger, Ethiopian cardamom (Aframomum corrorima), and 
turmeric. The most important cash crops in the area are coffee and khat (Catha edulis); sugarcane and eucalyptus tree are also cultivated in the study area. Livestock and their products are also common commodities produced in the area. The main livestock includes: cows (milk production), bulls, sheep and goats, poultry and apiculture. Maize and coffee are the dominant commodities produced with the aim of consumption and market, respectively.

\subsection{Homegardens in YCFBR}

The traditional agroforestry systems in YCFBR in south-western Ethiopia are among the most widespread and best performing agroforestry practices, and support the livelihoods of the local population while maintaining environmental integrity (Assesfa, 2010; Sentra et al., 2013).Homegardens of transitional zone of YCFBR encompass a mix of useful plants including staple crops like Enseteventricosum and Zea mays, tuber and root crops, e.g., anchote (Coccinia abyssinica), taro (Colocasia antiquorum), potato (Solanum tuberosum) and sweet potato (Ipomoea batatas), leafy and othervegetables, e.g., kale (Brassica oleracea) and hot pepper (Capsicum frutescens); exotic fruits, e.g.,papaya (Carica papaya), mango (Mangifera indica) and avocado (Persea americana), and some pulsecrops, e.g., haricot bean (Phaseolus vulgaris) and lima bean (Phaseolus lunatus) (Etissa et al., 2016; Jemal et al., 2018).

Species found in homegardens do not show a pre-determined spatial arrangement, with theexception of small plantations of Catha edulis. Rather, the location of individual plants and cohorts israndom and conveniently determined by the farmer's needs. For instance, spices are planted closerto the homestead, or shade-loving crops under fruit trees. In addition, species density is also variable depending on the household and market demand, and generally tends to increase based on the farmers aim to introduce and test potential useful species gathered elsewhere (Jemal et al., 2018).

\subsection{Methods}

\subsubsection{Study site selection}

The study sites (Kebeles, the smallest administrative unit in Ethiopia) and the district was selected purposefully. Three Kebeles (Hawayember, Sololo and Uta None) were selected for this study. The selection was based on their inclusion in YCFBR, and widespread practice of homegarden for the objective stated.

\subsubsection{Sample size and sampling techniques}

The sample size was determined using the method proposed by Yamane (1967).

$$
n=\frac{N}{1+N\left(e^{2}\right)}
$$

Where $\mathrm{n}$ is the sample size, $\mathrm{N}$ is the population size, and $\mathrm{e}$ is the desired level of precision.

$\mathrm{n}=865 / 1+865(0.14)^{2}=\approx 48$ Hawayember Kebele

$$
\begin{aligned}
& \mathrm{n}=381 / 1+381(0.14)^{2}=\approx 45 ; \text { Sololo Kebele } \\
& \mathrm{N}=447 / 1+447(0.14)^{2}=\approx 46 \text {; Sololo Kebele }
\end{aligned}
$$

Accordingly, a total of 139 households were determined and selected by systematic random sampling method from 1693 households list (of the three Kebeles) for an interview (Table 3 and Figure 3). The resulting sampling distribution of the study site by Kebeles is shown as in Table 4 below.

\begin{tabular}{|c|c|c|c|c|c|c|c|c|}
\hline & \multirow[t]{2}{*}{ Male } & \multirow[t]{2}{*}{ Female } & \multirow[t]{2}{*}{ Total } & \multirow[t]{2}{*}{ Random Interval } & \multirow[t]{2}{*}{ Random Start } & \multicolumn{3}{|c|}{ Sample Taken } \\
\hline & & & & & & Male & Female & Total \\
\hline Hawayember & 807 & 58 & 865 & 18 & 13 & 43 & 5 & 48 \\
\hline Sololo & 333 & 48 & 381 & 8 & 2 & 44 & 1 & 45 \\
\hline Uta None & 445 & 22 & 447 & 10 & 7 & 44 & 2 & 46 \\
\hline & 1585 & 128 & 1693 & & & 131 & 8 & 139 \\
\hline
\end{tabular}

Table 3: Total population and sample used for the study

Kebele Total number of Households Sample size per Kebele

$\mathrm{HG}=$ Homegerden 


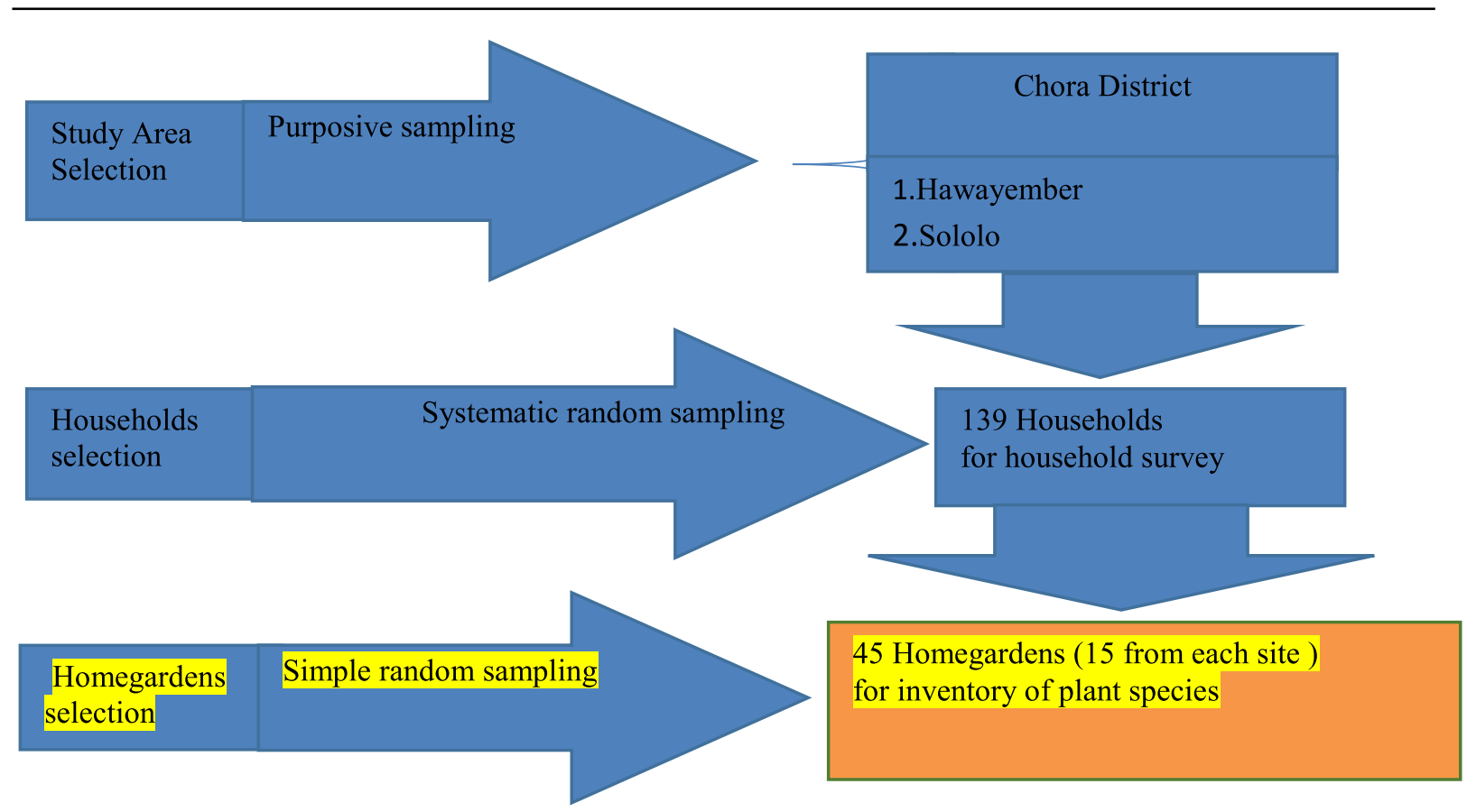

Figure 3: Schematic diagram of a sampling

\subsubsection{Data collection methods}

\subsubsection{Household survey}

Primary data were collected from the sample rural households using a semi-structured and structured questionnaire administered during October to December 2017. Prior to the actual administration of the general survey, the questionnaire was pre-tested, modified and refined. Data on homegarden contribution, with households demographic and socioeconomic(i.e. Age, family size, annual income, level of education, etc) were collected (Appendix 1-4).Household heads were interviewed to list their livelihood sources, products and their prices at the farm gate and/ or localmarket at the time of sellingto determine both totalincomes and that obtained from homegarden components (Appendix 1 and 4).

Note: The income determination in this study was based on the one year (2016/2017) yield and its prices estimation including both products consumed at home and sold in the market for income generation (i.e. those products around homestead were termed as homegardens and outside homestead as other sources) (Appendix 1 and 4).

In addition to the household survey, focus group discussions (FGDs) and key informant interviews (Table 4) and field observationwere undertaken. These methods were used to confirm the information given by an individual farmer and to catch important issues that were not raised by respondent farmers. Questions were asked in a structured conversational format (Appendix 5 and Appendix 6); allowing us to gather consistent data across gardens, while also learning about qualitative aspects of homegardens through farmers' perspectives and insights (Coomes and Ban, 2004).Secondary data were also collected from published and unpublished sources including information on the study area.

Table 4: Summary and descriptions of instruments

\begin{tabular}{lllll}
\hline No & $\begin{array}{l}\text { Types of } \\
\text { instruments }\end{array}$ & Target group & $\begin{array}{l}\text { Number of target } \\
\text { group } \\
\text { representations }\end{array}$ & $\begin{array}{l}\text { Types of } \\
\text { sampling }\end{array}$ \\
\hline 1 & Household survey & Selected household heads & 139 & $\begin{array}{l}\text { Systematic } \\
\text { random } \\
\text { sampling } \\
\text { Purposive } \\
\text { sampling }\end{array}$ \\
3 & Key informants & $\begin{array}{l}\text { Community leaders and experts, } \\
\text { model farmers and members of the } \\
\text { biosphere reserve management unit } \\
\text { Local community members }\end{array}$ & 15 & Purposive \\
& FGD & sampling
\end{tabular}

\subsubsection{Data Analysis}

Descriptive analysis through (percentage, frequency, mean, range, and standard deviation) and one way ANOVA were applied using IBM statistical package for social science SPSS version 20.0. 


\section{RESULTS AND DISCUSSION}

\subsection{Households characteristics}

The average age of the respondents was 42.9 with a standard deviation of 7.23 . The family size of the sampled households on average was six. The largest frequency in family size is seven family members per household, which was $27.8 \%$ of the sample households. The sampled household education level in the study area ranges from illiterate to complete secondary school. The total land size of each household mostly consists of the cropland, coffee plantation, and homegardens. The average farmland size was 1.6 hectare with the range of 0.5 to 3.5 hectare whereas about $56.5 \%$ of the households have farmland ranging from 1.5 to 2 hectare. Regarding the households annual income, the average household annual income is 31848.48 Birr. The size of homegarden in the study area ranges between 0.02 to 0.27 hectare, with the average of 0.14 hectare (Table 12), which is less than the mean homegarden size (0.185) reported by Linger (2014), for homegarden around Jabithenan District, Northwestern Ethiopia. About 29.3\% homegarden area was 0.18 hectare, while about $85.8 \%$ was less than 0.2 hectare.

Table 12: Characteristics of sampled households, $(n=139)$

\begin{tabular}{lllll}
\hline Household characteristics & Measuring system & Observed range & Mean & SD \\
\hline Age & Year & $\mathbf{2 8 - 6 7}$ & $\mathbf{4 2 . 9 1}$ & $\mathbf{7 . 2 3}$ \\
Total land size & Hectare & $\mathbf{0 . 5 - 3 . 5}$ & $\mathbf{1 . 6 0}$ & $\mathbf{0 . 6 7}$ \\
Homegarden land size & Hectare & $\mathbf{0 . 0 2 - 0 . 2 7}$ & $\mathbf{0 . 1 4}$ & $\mathbf{0 . 0 7}$ \\
Education & Year & $\mathbf{0 - 1 0}$ & $\mathbf{3 . 5}$ & $\mathbf{2 . 7 8}$ \\
Family size & Numbers & $\mathbf{3 - 1 7}$ & $\mathbf{6 . 2}$ & $\mathbf{1 . 8 6}$ \\
Annual income & Thousand & $\mathbf{1 0 - 6 5}$ & $\mathbf{3 1 5 3 5 . 9 6}$ & $\mathbf{1 0 0 1 7 . 4 9}$ \\
\hline
\end{tabular}

$\mathrm{SD}=$ Standard deviation

Source: Own data, Chora district, 2017,

\subsubsection{Major benefits of homegarden for households}

About $86.5 \%$ of the respondents agreed that homegarden provides high food products for their family. Whereas about $21.8 \%$ of the respondents agreed that homegarden used for high income generating and $47.4 \%$ of the respondents said that homegarden had a medium potential for income generating (Figure 4). These perceptions of the gardeners could probably imply that food crops in homegardens of the study area had a significant role to enhance nutritional and income status of the local people. Thus, along with the ecological benefits, homegardens provide potential food security to the householder. This result is agreed with Jemal et al. (2018), stating that homegarden, multistorey-coffee-system is mainly used to generate money and, for the majority of households, is the main, if not the only, source of cash. Most farmers use multipurpose-trees-on-farmlands to produce food, and homegarden is used for both a source of food and cash to supplement the other two practices. This result is agreed with Regassa (2016), reported that about $75 \%$ of the home gardeners explained that they conserve useful plant species for foods, around Hawassa, Ethiopia. Again, the result is also supported with the Mengistu and Fitamo (2016), in which they reported that diverse mixture of crops that are harvested at different times, and constant supply of food in a different form is available from homegardens.

The discussion held during the focus group discussion also supported that homegarden agroforestry used for a long period of food sustenance during the time of food shortage. They revealed that the canopy of the tree used as shade during high sunlight and warm weather. Although there is a shortage of land for homegarden, households get diverse products from such land as they cultivate it intensively. In general members of the group discussion household head respondents were agreed that homegarden practice contributes a lot and provide multiplebenefits from a small unit of land (Figure 5). This result is in agreement with findings of Kassa et al. (2015), stated that the agroforestry practices contribute to the conservation of biodiversity, while providing multiple products and services, in Yem district southern Ethiopia. 


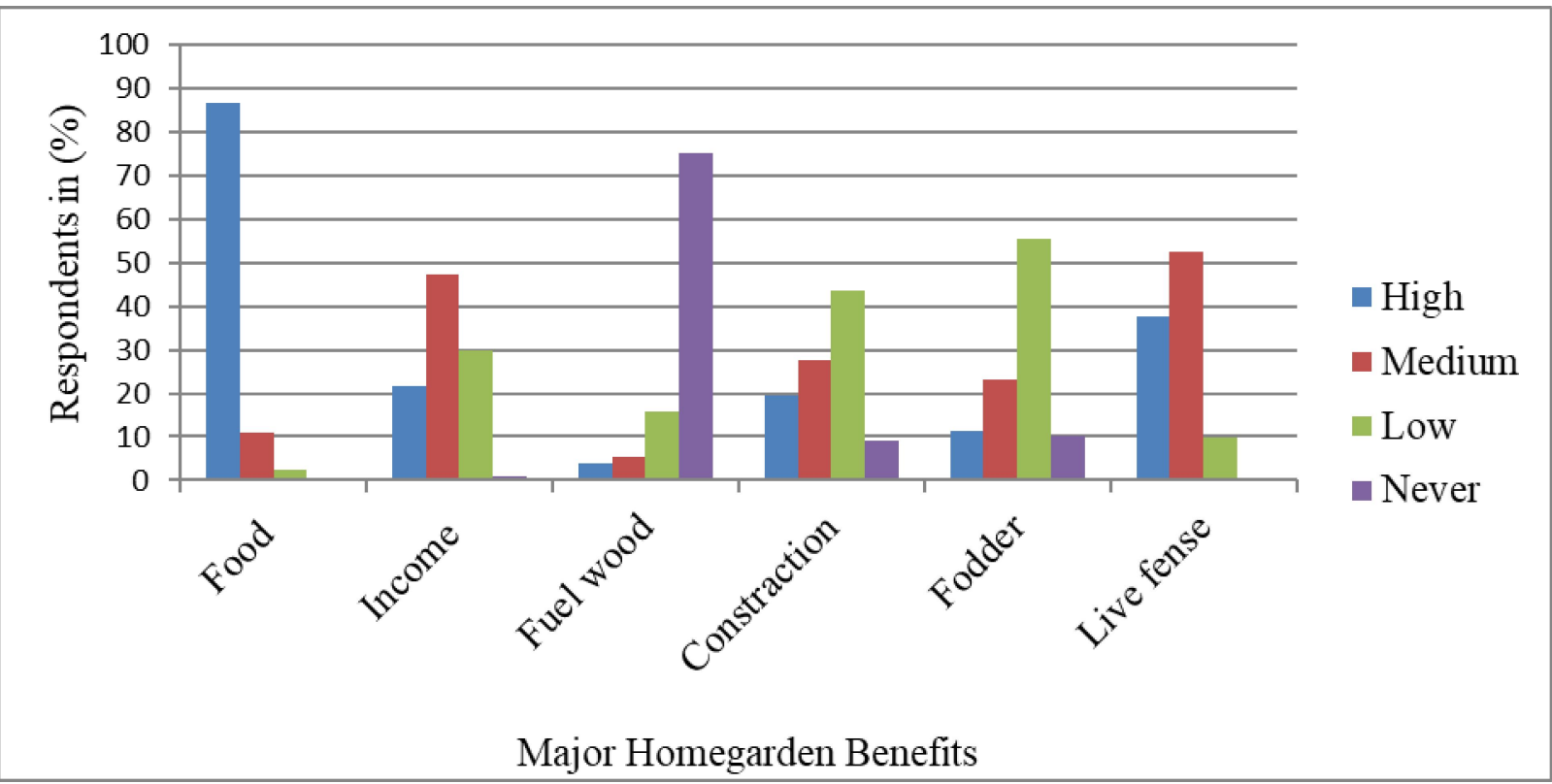

Figure 4: Major benefits of homegardens

\subsubsection{Homegardens as a source of income}

Homegarden annual income contribution for the households of the three Kebeles was not shown significant differences statistically, $\left(\mathrm{F}_{136,2}=0.281 ; \mathrm{p}=0.755\right)$. However, households in the study area generate income from different homegarden products. The homegardens contributions to household's annual income on average was about $13 \%$ of the total annual income (table 12 and Table 13), among which Catha edulis and coffee arabica homegardens produce share the main role, while the rest household income/economic contributors are from food source plants, such as fruit, spices, root and tubers, and vegetables in the practice (Figure 6).

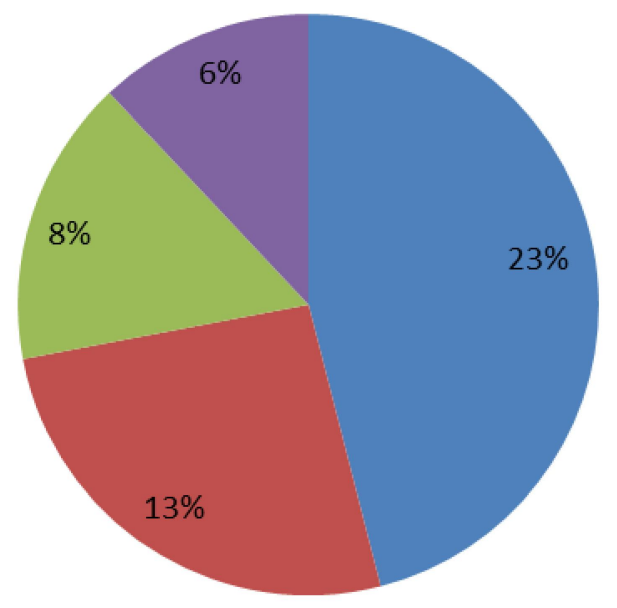

Fruits

- Spices

Root and tubers

Vegetables

Figure 5: Income generating food source components of homegarden (of the total recorded species)

Concurrently, over $90 \%$ of the respondents reported that coffee (which is mainly from coffee plantation site) is their greatest household financial source (i.e. total household annual income). Similarly, the discussion held during the focus group discussion also implies that villagers cultivate and maintain plants in their homegardens mainly for household consumption and surplus vegetables and fruits were sold in the nearby market for monetary benefits. The most marketed fruits and vegetables Persea americana, Mangifera indica, Musa sapietum, Lycopersicon esculentum, Brassica napus, and Brassica integrifolia. Similar findings were obtained by Jemal et al. (2018), Coffee forest production is mainly practices used to generate money for the majority of households, where homegarden is used as both a source of food and cash income generation for local community around Yayo, southwest Ethiopia.

The above finding is in agreement with the findings of Nischalke et al. (2017), reported Coffee is an important part of the cultural identity and the most important livelihood source for households around YCFBR. 
Similarly, the above finding is in agreement with the findings of Etissa et al. (2016), reported that many crops such as coffee, avocado, mango, banana, Enset, root and tubers, and many other crops grow in the sample homegardens of the households around YCFBR. The main structural arrangements in most homegardens are primarily coffee mixed with trees and shrubs, fruit trees or planted in strips, or planted as a boundary and fence, edges of plots and fields mainly for coffee shades, and live fence. From these trees including fruit trees farmers get food, fodder for their livestock, fuel wood and other wood products and other uses such as a windbreak and shades.

However, the above findings are slightly different from the findings of Regassa (2016), who reported that $35 \%$ household's annual income contribution from homegardens around Hawassa, Southern Ethiopia. The difference might be due to the livelihood sources and lifestyles of society living in the two areas (Hawassa city and those of Chora rural villages), and finding of Gebrehiwot (2017), in the same area, reported that over $50 \%$ of the Sidama community generate their household financial income mainly from coffee. Similarly, Mbow et al. (2014), stated that homegardens enhance smallholder's resilience by providing food for household consumption and to sell surplus food products to supply other needed items. Hence, this farming practice enhances and maintains human capital (health and education) for the rural community. It accomplishes this through continuous production and supply of food, nutrition, and financial income. According to Morse et al. (2009), livelihood outcomes include more stable income, increased human wellbeing, improved food security, and sustainability.

Table 2: Annual incomes from homegarden

\begin{tabular}{llll}
\hline Level of income & \multicolumn{4}{l}{ Income in Ethiopian Birr per site } & \\
\hline & \multicolumn{4}{l}{ Cash income (Birr) $1 \$=27$ Birr when the research conducted (the Year 2017) } \\
\hline Level of income & Hawayember & Sololo & Uta None \\
\hline Max income & 17000.00 Birr & 19700.00 Birr & 23500.00 Birr \\
Min income & 1200.00 Birr & 900.00 Birr & 1100.00 Birr \\
Average income & 4095.65 Birr & 4351.16.00 Birr & 3797.73 Birr \\
\hline
\end{tabular}

Average annual income 4079.70 Birr

Source: Household survey, Chora, 2017

\subsection{Limitation of the Research}

Even though this research was carefully prepared, I am still aware of its limitations and shortcomings. First of all, the research was conducted based the data collected for three months, which is not enough for the researcher to assess enough information on the homegarden role. It would be better if it was done in a longer time. Second, the population of the experimental group is small, only one hundred thirty nine households might not represent the majority of the households in the biosphere reserve. Third, since the questionnaire designed to measure the households' annual income of one year. It might give useful information about the role of homegarden to local household livelihood; it seems not to provide enough evidence of the exact role played by homegarden.

\subsection{Conclusions and Recommendation \\ 4.3.1. Conclusions}

Homegarden agroforestry practices in YCFBR plays a remarkable role in improving food and nutrition security for households residing in transitional (utilization zone) of the biosphere. The results of the study revealed that homegarden agroforestry practices in the present study area have been providing multiple benefits for the locals and playing significant contribution for the communities' livelihood in the area. The society mainly dependent on diverse plants of different uses in the system for food sources of the family. However, more of the plant species were exotic species in their origin and concentration on few species in the garden were observed. Cultivation of cash crop production particularly, coffee arabica and Catha edulis in homegarden agroforestry practices are attracting more attention of the farming households with the objective of maximizing their cash benefit and concurrently to escape from increased wildlife damage to food crop components in the garden. These situations are happening at the expense of species diversity and bringing a reduction in food provision for poor rural households. Thus, local people livelihood sustenance has been affected. Yet, clear capacity exists to make a homegarden contribution more effective towards of livelihood improvement.

\subsubsection{Recommendations}

Based on the findings of this study, the following recommendations are suggested:

$>$ Attention should be given to make homegarden more effective in local people livelihood improvement.

$>$ Promotion of homegardens should be included in the programmes of conservation agency and others concerned bodies to enhance the livelihoods of rural poor.

$>$ Further study is recommended and needed to find available opportunities in supplying plant varieties of ecological and locals' needs. 


\section{REFERENCES}

Abdoellah O. S, Hadikusumah H. Y, Takeuchi K, SatoruOkubo S, and Parikesit. 2006 Commercialization of homegardens in an Indonesian village: vegetation composition and functional changes. Agroforestry Systems 68: 1-13.

Abdoellah, O.S., Parikesit, B.G. and Hadikusumah, H.Y., 2002. Homegardens in the upper citarum watershed, West Java: a challenge for in-situ conservation of plant genetic resources. Homegardens and in-situ conservation of plant genetic resources in farming systems, 140.

Abebe, T. Sterck, F.J. Wiersum, K.F. and Bongers, F. 2013. Diversity, composition, and density of trees and shrubs in agroforestry homegardens in Southern Ethiopia. Agroforestry systems, 87(6):1283-1293.

Abebe, T., 2005. Diversity in homegarden agroforestry systems of Southern Ethiopia.

Abebe, T., K. F. Wiersum, and F. Bongers. "Spatial and temporal variation in crop diversity in agroforestry homegardens of southern Ethiopia."Agroforestry systems 78, no. 3 (2010): 309-322.

Abrol, D.P., 2012. Consequences of introduced honeybees upon native bee communities. In Pollination Biology. Springer, Dordrecht.

Acheampong, E., Guuroh, R.T. and Holm, U., 2012. Homegardens as a Source of Income for Rural Households: A Case Study of Bieha District, Southern Burkina Faso.

Agbogidi, O.M. And Adolor, E. B. (2014). Homegardens in the Maintenance of Biological Diversity, 8330(1): 4-19.

Ajah, A.I. Agera, S.I.N. and Ejembi, S.E. 2013. Prospects of the contribution of Homegardens to food security in our households. Journal of Research in Forestry, Wildlife, and Environment, 5(1): 23-27

Albuquerque, U.D., Andrade, L.D.H.C. and Caballero, J., 2005. Structure and floristics of homegardens in Northeastern Brazil. Journal of arid environments, 62(3):491-506.

Altieri, M.A., 2009. Agroecology, small farms, and food sovereignty. Monthly review, 61(3):102-113.

Ango, T.G., B örjeson, L., Senbeta, F. and Hylander, K., 2014. Balancing ecosystem services and disservices: smallholder farmers' use and management of forest and trees in an agricultural landscape in southwestern Ethiopia. Ecology and Society, 19(1).

Anjulo, A. and Mezgebu, A., 2016. Determinants of Agroforestry Practicing at Fogera District, Northwestern Ethiopia.

Assefa A.D. 2010. Local institutions and their influence on forest resource management in southwest of Ethiopia: The case of Yayo forest. A master thesis, Addis Ababa University.

Asfaw, Z. and Tadesse, M. (2001). Prospects for sustainable use and development of wild food plants in Ethiopia. Economic Botany, 55(1):47-62. doi.org/10.1007/BF02864545.

Barrow, C.J., 2016. Water resources and agricultural development in the tropics. Routledge.

Barthel, S. and Isendahl, C. 2013. Urban gardens, agriculture, and water management: Sources of resilience for long-term food security in cities. Ecological Economics, 86:224-234.

Beery, T., Jönsson, K.I. and Elmberg, J., 2015. From environmental connectedness to sustainable futures: Topophilia and human affiliation with nature. Sustainability, 7(7):8837-8854.

Bekalo, T.H., Woodmatas, S.D. and Woldemariam, Z.A., 2009. An ethnobotanical study of medicinal plants used by local people in the lowlands of Konta Special Woreda, southern nations, nationalities and peoples regional state, Ethiopia. Journal of Ethnobiology and Ethnomedicine, 5(1): 26.

Bekele, A. and Tengn äs, B., 2007. Useful trees and shrubs of Ethiopia: identification, propagation, and management for 17 agroclimatic zones. RELMA in ICRAF Project, World Agroforestry Centre, Eastern Africa Region.

Berhanu, A. And Asfaw, Z. 2014. The Role Of Homegardens For Conservation And Sustainable Utilization Of Plant Biodiversity Of Ethiopia.

Bharucha, Z. and Pretty, J. 2010. The roles and values of wild foods in agricultural systems. Philosophical Transactions of the Royal Society of London B: Biological Sciences, 365(1554): 2913-2926.

Bijalwan, A., 2012. Structure, composition, and diversity of horticulture trees and agricultural crops productivity under a traditional agri-horticulture system in mid hill situation of Garhwal Himalaya, India. American Journal of Plant Sciences, 3(04):480.

Black, R. 2016. Refugees, environment, and development. Routledg.

Blanckaert, I., Swennen, R.L., Flores, M.P., López, R.R. and Saade, R.L., 2004. Floristic composition, plant uses and management practices in homegardens of San Rafael Coxcatl án, Valley of Tehuac án-Cuicatl án, Mexico. Journal of Arid Environments, 57(2):179-202.

Brownrigg, L.A., 1985. Homegardening in international development: what the literature shows, including an annotated bibliography, and inventories of international organizations involved in homegardening and their projects.

Calvet-Mir, L. March, H. Corbacho-Monn é, D. Gómez-Baggethun, E. and Reyes-Garc á, V. 2016. Homegarden ecosystem services valuation through a gender lens: a case study in the Catalan Pyrenees. Sustainability, 
8(8):718.

Carley, M. and Christie, I. 2010. Managing sustainable development. Routledge.

CBD (2005). Handbook of the Convention on Biological Diversity Including its Cartagena Protocol on Biosafety, 3rd edition, Secretariat of the Convention on Biological Diversity (Montreal, Canada): 1492.

CBD, 2009. Convention on Biological Diversity (CBD). 2009. Global Biodiversity Outlook 2. www.biodiv.org/GBO2 (accessed Nov 2009). Elevitch, (October)

Chambers, R. and Conway, G., 1992. Sustainable rural livelihoods: practical concepts for the 21 st century. Institute of Development Studies (UK).

Chandrashekara, U.M., 2009. Tree species yielding edible fruit in the coffee-based homegardens of Kerala, India: their diversity, uses.

Chappell, M.J. and LaValle, L.A. 2011. Food security and biodiversity: can we have both? An agroecological analysis. Agriculture and Human Values, 28(1): 3-26

Coetzer, K.L., Witkowski, E.T. and Erasmus, B.F., 2014. Reviewing Biosphere Reserves globally: effective conservation action or bureaucratic label?. Biological Reviews, 89(1):82-104.

Coomes, O.T. and Ban, N., 2004. Cultivated plant species diversity in Homegardens of an Amazonian peasant village in northeastern Peru. Economic Botany, 58(3):420-434.

CSA, Central Statistical Agency. 2008. Summary and Statistical Report of the 2007 population and Housing Census. Population size by age and sex. Addis Ababa.

Dagar, J.C., and Tewari, V.P., 2017. Evolution of Agroforestry as a Modern Science. In Agroforestry (13-90). Springer, Singapore.

Das, T. and Das, A.K., 2005. Inventorying plant biodiversity in homegardens: A case study in Barak Valley, Assam, North East India. Current science, 155-163.

Devi, N.L. and Das, A.K., 2013. Diversity and utilization of tree species in Meitei homegardens of Barak Valley, Assam. Journal of Environmental Biology, 34(2):211.

Dorsey, K. 2009. The dawn of conservation diplomacy: US-Canadian wildlife protection treaties in the progressive era. University of Washington Press.

Edwards, S., Tadese, M. and Hedberg, I., 1995. Flora of Ethiopia and Eritrea vol. 2, Part 2: canellaceae to euphorbiaceae. AAU.

Emmett, R.S. and Nye, D.E. 2017. The environmental humanities: a critical introduction. MIT Press.

Engels J. 2001. Homegardens- a genetic resource perspective. In: Watson J.W, Eyzaguirre P.B. eds. Proceedings of the second international Homegardenworkshop. Biodiversity International, Rome, Italy, 3-9.

Eyzaguirre, P.B., and Linares, O.F., 2004. Homegardens and agrobiodiversity. Smithsonian Books.

Fabricant, D.S. and Farnsworth, N.R., 2001. The value of plants used in traditional medicine for drug discovery. Environmental health perspectives, 109(Suppl 1):69.

Frys, W. and Nienaber, B., 2011. Protected areas and regional development: conflicts and opportunitiespresented on the example of the UNESCO biosphere reserve Bliesgau. European countryside, 3(3): 208226.

Galhena, D.H. Freed, R. and Maredia, K.M. 2013. Homegardens: a promising approach to enhance household food security and wellbeing. Agriculture and Food Security, 2(1):8.

Galluzzi, G. Eyzaguirre, P., and Negri, V. 2010. Homegardens: neglected hotspots of agro-biodiversity and cultural diversity. Biodiversity and conservation, 19(13): 35-36

Gardner TA, Barlow J, Chazdon R, Ewers RM, Harvey CA, Peres CA, Sodhi NS. 2009. Prospects for tropical forest biodiversity in a human-modified world. Ecol Lett. 12(6):561-582.

Gatzweiler, F. Reichhuber, A. and Hein, L. 2007. Why financial incentives can destroy economically valuable biodiversity in Ethiopia (No. 115). ZEF discussion papers on development policy.

Gebrehiwot, M. 2013. Recent transitions in Ethiopian homegarden agroforestry (Vol. 21).

Gebrehiwot. (2017). Agroforestry homegardens in Ethiopia : rural livelihoods in transition.

Gedefa, B. 2015. For sustainable production and utilization of wheat in sub-humid areas in Western Oromia in Sayo and Chora districts, Ethiopia. Scientia, 12(2):58-71.

Goddard, M.A., Dougill, A.J. and Benton, T.G., 2010. Scaling up from gardens: biodiversity conservation in urban environments. Trends in ecology and evolution, 25(2):90-98.

Godfray, H.C.J. Beddington, J.R. Crute, I.R. Haddad, L. Lawrence, D. Muir, J.F. Pretty, J. Robinson, S. Thomas, S.M. and Toulmin, C. 2010. Food security: the challenge of feeding 9 billion people. Science, 327(67): 812818

Gole, T.W., Borsch, T., Denich, M. and Teketay, D., 2008. Floristic composition and environmental factors characterizing coffee forests in southwest Ethiopia. Forest Ecology and Management, 255(7), pp.2138-2150.

Gole, T.W., Feyera, S., Kassahun, T. and Fite, G., 2009. Yayo coffee forest biosphere reserve nomination form. Ethiopian MAB National Committee, Addis Ababa.

Haile, G. Lemenih, M. Senbeta, F. and Itanna, F. 2017. Plant diversity and determinant factors across 
smallholder agricultural management units in Central Ethiopia. Agroforestry Systems, 91(4): 677-695.

Hedberg, I., Friis, I. and Edwards, S., 2004. Flora of Ethiopia and Eritrea, Vol. 4, Part 2: Asteraceae (Compositae). Addis Ababa: The National Herbarium and Uppsala: The Department of Systematic Botany.

Hedberg, I., Kelbessa, E., Edwards, S., Demissew, S. and Persson, E., 2006. Flora of Ethiopia and Eritrea, Volume 5: Gentianaceae to Cyclocheilaceae. Addis Ababa, Ethiopia, and Uppsala, Sweden: The National Herbarium, Addis Ababa University.

Heywood, V.H. (1998). The species concept as a socio-cultural phenomenon: a source of scientific dilemma. Theory in Biosciences 117: 203-212.

Hooper, D.U., Chapin, F.S., Ewel, J.J., Hector, A., Inchausti, P., Lavorel, S., Lawton, J.H., Lodge, D.M., Loreau, M., Naeem, S. and Schmid, B., 2005. Effects of biodiversity on ecosystem functioning: a consensus of current knowledge. Ecological Monographs, 75(1):3-35.

Hunde D, Asfaw Z, Kelbessa E (2006). Use of traditional medicinal plants by people of 'Boosat' sub-district, central eastern Ethiopia. Ethiop. J Health Sci. 16(2):141-155

Jaganmohan, M. Vailshery, L.S. Gopal, D. and Nagendra, H. 2012. Plant diversity and distribution in urban domestic gardens and apartments in Bangalore, India. Urban Ecosystems, 15(4):911-925.

Jama, B., Kwesiga, F. and Niang A. 2006. Agroforestry innovations for soil fertility management in sub-Saharan Africa: Prospects and challenges ahead. World Agroforestry into the Future, 60

Jeeva, S. 2016. Plant diversity community characteristics and economic importance of traditional Homegardens in allankottai and its environs.

Jemal, O., Callo-Concha, D., and van Noordwijk, M., 2018. Local Agroforestry Practices for Food and Nutrition Security of Smallholder Farm Households in Southwestern Ethiopia. Sustainability, 10(8):2722.

Jerneck, A. and Olsson, L., 2013. More than trees! Understanding the agroforestry adoption gap in subsistence agriculture: Insights from narrative walks in Kenya. Journal of Rural Studies, 32:114-125.

Jhariya, M.K., Bargali, S.S. and Raj, A., 2015. Possibilities and Perspectives of Agroforestry in Chhattisgarh. In Precious Forests-Precious Earth. InTech.

John, J. and Nair, M.A. 1999. Socio-economic of homestead farming in south Kerala, Journal of Tropical Agriculture, 37: 107-109.

Jose, S., 2012. Agroforestry for conserving and enhancing biodiversity. Agroforestry Systems, 85(1):1-8.

Kabir, M.E. and Webb, E.L., 2009. Household and homegarden characteristics in southwestern Bangladesh. Agroforestry systems, 75(2):129.

Kassa, D.G., Ege, S. and Aspen, H., 2009. Resettling the discourse on 'resettlement schemes': towards a new approach. In Proceedings of the 16th international conference of Ethiopian studies. Trondheim Norway (867-880).

Kassa, G. Abebe, T. and Ewnetu, Z. (2015). Diversity, Density and Management of Trees in Different Agroforestry Practices of Yem Special District, Southern Ethiopia, 38(1):1-16.

Kaswanto, R.L. 2017. Management of Landscape Services for Improving Community Welfare in West Java, Indonesia. In Landscape Ecology for Sustainable Society (251-270). Springer, Cham.

Kaushal, K., and Kala, J. C. (2014). Applying the sustainable livelihood approach to joint forest management projects in India. The International Forestry Review 6:13-18.

Kebebew, Z. and Urgessa, K. 2011. Agroforestry perspective in land use pattern and farmers coping strategy: experience from southwestern Ethiopia. World J Agric Sci, 7: 73-77.

Kebede, T.M. 2010. Homegardens agrobiodiversity conservation in Sebeta-Hawas Wereda, southwestern Shewa Zone of Oromia Region, Ethiopia (Doctoral dissertation presented at Addis Ababa University, Ethiopia)

Kehlenbeck, K., Arifin, H. S. and Maass, B. L., 2007. Plant diversity in homegardens in a socio-economic and agro-ecological context. In: T. Tscharntke, et al. eds. The stability of tropical rainforest margins, linking ecological, economic and social constraints of land use and conservation. Berlin, Germany: Springer, 297319.

Kelbessa E, Demissew S, Woldu Z, Edwards S: Some threatened Endemic plants of Ethiopia. In The status of some plants in parts of tropical Africa. Edited by Edwards S, Zemede A. East and Central Africa: NAPRECA, No.2. Botany 2000; 1992:35-55.

Kelecha, W.M., 1987. A glossary of Ethiopian plant names.

Kent, M. and Coker, P., 1992. Vegetation description and analysis. Boca Raton, CRC.

Kitalyi, A. Wambugu, R.O. and Kimaro, D. 2013. FAO characterization of global heritage agroforestry systems in Tanzania and Kenya. Agroforestry and development alternatives (AFOREDA), Tanzania. FAO, Rome Google Scholar.

Kitalyi, A. Wambugu, R.O. and Kimaro, D. 2013. FAO characterization of global heritage agroforestry systems in Tanzania and Kenya. Agroforestry and development alternatives (AFOREDA), Tanzania. FAO, Rome Google Scholar.

Kittur, B. and Bargali, S.S., 2013. Perspectives of agroforestry: Present and future facets. Journal of Progressive 
Agriculture, 4(2): 91-94.

Krantz, L., 2001. The sustainable livelihood approach to poverty reduction. SIDA. Division for Policy and Socioeconomic Analysis.

Kumar and Nair, 2006. Tropical Homegardens: A Time-Tested Example of Sustainable Agroforestry. Environmental Experts, India Mcneely: 1-9.

Kumar, B.M. and Nair, P.R. 2004. The enigma of tropical homegardens. Agroforestry systems, 61(1-3):135-152.

Lambin, E.F., and Meyfroidt, P. 2011. Global land use change, economic globalization, and the looming land scarcity. Proceedings of the National Academy of Sciences, 108(9): 3465-3472.

Lamprecht, H. 1989. Silviculture in the tropics: tropical forest ecosystems and their tree species: possibilities and methods for their long-term utilization (No. 634.95 L239s ing.). Eschborn, DE: GTZ

Linger, E. 2014. Agro-ecosystem and socioeconomic role of Homegarden agroforestry in Jabithenan District, North-Western Ethiopia: implication for climate change adaptation. Springer plus, 3(1): 154

Lope-Alzina, D.G. and Howard, P.L. 2012. The structure, composition, and functions of homegardens: focus on the Yucat án Peninsula. Etnoecológica, 9(1) : 17-41.

Lulandala, L.L.L. 2011. Agroforestry Concepts, Systems, Practices, Potentials, Constraints, Research, and Training Needs.

Magcale-Macandog, D.B. Ra ñola, F.M. Rañola, R.F. Ani, P.A.B. and Vidal, N.B. 2010. Enhancing the food security of upland farming households through agroforestry in Claveria, Misamis Oriental, and Philippines. Agroforestry systems, 79(3):327-342.

Maroyi, A. 2009. Traditional homegardens and rural livelihoods in Nhema, Zimbabwe: a sustainable agroforestry system. International Journal of Sustainable Development and World Ecology, 16(1): 1-8.

Mbow C., Noordwijk M., Prabhu R., and Simons T., (2014 a) Knowledge gaps and research needs concerning agroforestry's contribution to Sustainable Development Goals in Africa, Current Opinion in Environmental Sustainability, 6: 162-170

Mekonen, T. Giday, M. and Kelbessa, E. 2015. Ethnobotanical study of Homegarden plants in Sebeta-Awas District of the Oromia Region of Ethiopia to assess use, species diversity, and management practices. Journal of Ethnobiology and ethnomedicine, 11(1): 64.

Mekonnen, E.L., Asfaw, Z., and Zewudie, S., 2014. Plant species diversity of homegarden agroforestry in Jabithenan District, North-Western Ethiopia. International Journal of Biodiversity and conservation, 6(4):301-307.

Méndez, V.E., Lok, R. and Somarriba, E., 2001. Interdisciplinary analysis of homegardens in Nicaragua: microzonation, plant use, and socioeconomic importance. Agroforestry systems, 51(2):85-96.

Mengitu, M. and Fitamo, D., Plant Species Diversity and Composition of the Homegardens in Dilla Zuriya Woreda, Gedeo Zone, SNNPRS, Ethiopia.

Mercer, D.E. and Miller, R.P., 1998. Socioeconomic research in agroforestry: progress, prospects, priorities. In Directions in Tropical Agroforestry Research (177-193). Springer, Dordrecht.

Mohri, H. Lahoti, S. Saito, O. Mahalingam, A. Gunatilleke, N. Hitinayake, G. Takeuchi, K. and Herath, S. 2013. Assessment of ecosystem services in Homegarden systems in Indonesia, Sri Lanka, and Vietnam. Ecosystem Services, 5:124-136.

Mooney, H. Larigauderie, A. Cesario, M. Elmquist, T. Hoegh-Guldberg, O. Lavorel, S. Mace, G.M. Palmer, M. Scholes, R. and Yahara, T. 2009. Biodiversity, climate change, and ecosystem services. Current Opinion in Environmental Sustainability, 1(1):46-54.

Morse, W.C., Schedlbauer, J.L., Sesnie, S.E., Finegan, B., Harvey, C.A., Hollenhorst, S.J., Kavanagh, K.L., Stoian, D., and Wulfhorst, J.D. 2009. Consequences of environmental service payments for forest retention and recruitment in a Costa Rican biological corridor. Ecology and Society 14(1): 23.

Motiur, R.M. Furukawa, Y. Kawata, I. Rahman, M.M. and Alam, M. 2006. Role of homestead forests in household economy and factors affecting forest production: a case study in southwest Bangladesh. Journal of Forest Research, 11(2):89-97.

Muhamad, D. Okubo, S. Harashina, K. Gunawan, B. and Takeuchi, K. 2014. Living close to forests enhances people' s perception of ecosystem services in a forest-agricultural landscape of West Java, Indonesia. Ecosystem Services, 8:197-206.

Nayar, N.M. 2010. 2 The Bananas: Botany, Origin, Dispersal. Horticultural Reviews, 36:117.

Neelamegam, R., Pillai, V., Anishal, A. and Reselin, S., 2015. Status and composition of home garden plants in rural and urban areas in Kanyakumari District, Tamil Nadu, India. Scholars Academic Journal of Biosciences, 3(8):656-667.

Olango, T.M. Tesfaye, B. Catellani, M. and P è, M.E. 2014. Indigenous knowledge, use and on-farm management of enset (Ensete ventricosum (Welw.) Cheesman) diversity in Wolaita, Southern Ethiopia. Journal of Ethnobiology and ethnomedicine, 10(1): 41.

Panda, N. K. Bhol, N., and Nayak, A. (2018). Spatiotemporal arrangement of plants and livestock in the HGs of 
coastal Odisha, 7(1): 814-819

Pandey, C.B., Lata, K., Venkatesh, A. and Medhi, R.P., 2006. Diversity and species structure of home gardens in South Andaman. Tropical Ecology, 47(2):251-258.

Panwar, P. and Kaushal, R. 2017. Agroforestry for Increased Production and Livelihood Security. New Indian Publishing Agency.

Parihaar, R.S., Bargali, K. and Bargali, S.S., 2015. Status of an indigenous agroforestry system: a case study in Kumaun Himalaya, India. Indian Journal of Agricultural Sciences, 85(3):442-447.

Peet, R.K. 1974. The measurement of species diversity. Annual review of ecology and systematics, 5(1): 285 307

Phelps, J. Carrasco, L.R. Webb, E.L. Koh, L.P. and Pascal, U. 2013. Agricultural intensification escalates future conservation costs. Proceedings of the National Academy of Sciences, 110(19):7601-7606.

Pingel, F., 2010. UNESCO guidebook on textbook research and textbook revision. Unesco.

Polegri, L. and Negri, V., 2010. Molecular markers for promoting agro-biodiversity conservation: a case study from Italy. How cowpea landraces were saved from extinction. Genetic resources and crop evolution, 57(6):867-880.

Pulido, M.T., Pagaza-Calder ón, E.M., Mart ńez-Ballest é, A., Maldonado-Almanza, B., Saynes, A. and Pacheco, R.M., 2008. Homegardens as an alternative for sustainability: challenges and perspectives in Latin America. Current topics in ethnobotany, 37:1-25.

Puri, S. and Nair, P.K.R., 2004. Agroforestry research for development in India: 25 years of experiences of a national program. Agroforestry Systems, 61(1-3):437-452.

Regassa, R., 2016. Useful plant species diversity in homegardens and its contribution to household food security in Hawassa city, Ethiopia. African Journal of Plant Science, 10(10):211-233.

Scales, B.R. and Marsden, S.J., 2008. Biodiversity in small-scale tropical agroforests: a review of species richness and abundance shifts and the factors influencing them. Environmental conservation, 35(2):160-172.

Schmitt, C.B., Senbeta, F., Denich, M., Preisinger, H. and Boehmer, H.J., 2010. Wild coffee management and plant diversity in the montane rainforest of southwestern Ethiopia. African Journal of Ecology, 48(1): 78-86.

Schroth, G. and Sinclair, F.L. eds., 2003. Trees, crops, and soil fertility: concepts and research methods. CABI.

Schumacher, E.F., 2011. Small is beautiful: A study of economics as if people mattered. Random House.

Scoones, I., 1998. Sustainable rural livelihoods: a framework for analysis.

Senbeta, F., Schmitt, C., Denich, M., Demissew, S., Velk, P.L., Preisinger, H., Woldemariam, T. and Teketay, D., 2005. The diversity and distribution of lianas in the Afromontane rain forests of Ethiopia. Diversity and Distributions, 11(5): 443-452.

Senbeta, F. and Denich, M. 2006. Effects of wild coffee management on species diversity in the Afromontane rainforests of Ethiopia. Forest Ecology and Management, 232(1-3):68-74.

Seyoum Aragaw, H., 2017. Nutritional potential of underutilized edible plants in agroforestry systems of Yayo, Southwestern Ethiopia (Doctoral dissertation, University of Bonn).

Shannon C, E. Wiener, W. (1949). The Mathematical Theory of Communication. University of Illinois Chicago, USA.

Sileshi, G. Akinnifesi, F.K. Ajayi, O.C. Chakeredza, S. Kaonga, M. and Matakala, P.W. 2007. Contributions of agroforestry to ecosystem services in the Miombo eco-region of eastern and southern Africa. African Journal of environmental science and technology, 1(4):68-80.

Sinku, S.K. 2016. Floristic Composition and Diversity of homegardens in Angara Block, Ranchi, Jharkhand (Doctoral dissertation, Birsa Agricultural University, Kanke, Ranchi, Jharkhand).

Smith RM, Thompson K, Hodgson JG. 2006. Urban domestic gardens (IX): composition and richness of the vascular plant flora and implications for native biodiversity. Biological Conservation 129: 312-322.

Tolera, M., Asfaw, Z., Lemenih, M. and Karltun, E., 2008. Woody species diversity in a changing landscape in the south-central highlands of Ethiopia. Agriculture, ecosystems and environment, 128(1-2):52-58.

Trinh, L.N., Watson, J.W., Hue, N.N., De, N.N., Minh, N.V., Chu, P., Sthapit, B.R. and Eyzaguirre, P.B., 2003. Agrobiodiversity conservation and development in Vietnamese Homegardens. Agriculture, Ecosystems and Environment, 97(1-3):317-344.

Tshiguvho, T. 2008. Sacred traditions and biodiversity conservation in the forest montane region of Venda, South Africa. Clark University.

Tynsong, H. and Tiwari, B.K. 2010. Plant diversity in the homegardens and their significance in the livelihoods of War Khasi community of Meghalaya, North-east India. Journal of Biodiversity, 1(1):1-11.

Van Asten, P. Ochola, D. Wairegi, L. Nibasumba, A. Jassogne, L. and Mukasa, D. 2013. Coffee-banana intercropping: Implementation guidance for policymakers and investors

Weber, A.S. 2011. Folk medicine in Oman. International Journal of Arts and Sciences, 4(23):237.

Woldegeorgis, G. and Wube, T. 2012. A Survey on Mammals of the Yayo Forest in Southwest Ethiopia. SINET: Ethiop. J. Sci., 35(2):135-138 
Woldeyes, F., Asfaw, Z., Demissew, S. and Roussel, B., 2016. Homegardens (Aal-oos-gad) of the Basket People of Southwestern Ethiopia: Sustainable agro-ecosystems characterizing a traditional landscape. Ethnobotany Research and Applications, 14: 549-563.

Yamane, Taro.(1967).Statistics, An Introductory Analysis,2nd.,New York:Harper and Row

Zaman, S., Siddiquee, S.U. and Katoh, M., 2010. Structure and diversity of homegarden agroforestry in Thakurgaon District, Bangladesh. The Open Forest Science Journal, 3:38-44.

Zimik, L., Saikia, P. and Khan, M.L., 2012. Comparative study on homegardens of Assam and Arunachal Pradesh in terms of species diversity and plant utilization pattern. Research Journal of Agricultural Sciences, 3(3):611-618.

\section{APPENDICES}

Appendix 1: Households Interview Questionnaires

\section{Jimma University}

\section{College Of Agriculture and Veterinary Medicine}

Dear respondents: My name is Gemeda Terfassa, this is the research questionnaires to collect the research data from households in Chora for the objective of MSc thesis work to study "The Role of Homegarden Agroforestry in Households Livelihoods at Yayo Coffee Forest Biosphere Reserve, Chora District, Southwestern Ethiopia" this study is conducted is conducted within the NutriHAF Africa project In collaboration with ECFF. It is research for my Masters thesis. This is for generating information about the system in contribution in the area. I would like to assure you that the information that you are giving used only for this study and honestly your name will not be mentioned in the report. Thank you in advance!

Part I: Basic information

Name ---------------- Kebele ------ specific site

North: $\quad$ East: $\quad$ Altitude (m.a.s.1.): $\quad$ Accuracy: GPS coordinates of residence (coordinates):

Current....?

1 Age in year

2 Family size

3 Total land size in ha

4 Homegarden land size in ha

5 Education level completed in year

6 Total annual income

Appendix 2: Check list for total income calculation

\begin{tabular}{|c|c|c|c|c|c|c|}
\hline \multirow{2}{*}{$\begin{array}{l}\text { Main Sources of } \\
\text { household income }\end{array}$} & & \multicolumn{4}{|c|}{ Major products } & \\
\hline & & Maize & Sorghum & Millet & Others & \\
\hline & $\begin{array}{l}\text { Yields in } \mathrm{Kg} \text { or } \\
\text { kuntal/ha/year }\end{array}$ & & & & & \\
\hline & Price & & & & & \\
\hline \multirow{3}{*}{$\begin{array}{l}\text { Coffee from the } \\
\text { forest (coffee } \\
\text { plantation) }\end{array}$} & & Coffee & Fuelwood & $\begin{array}{l}\text { Contraction } \\
\text { wood }\end{array}$ & Honey & Others \\
\hline & $\begin{array}{l}\text { Yield in } \mathrm{Kg} \text { or } \\
\text { kuntal/ha /year }\end{array}$ & & & & & \\
\hline & Price & & & & & \\
\hline \multirow[t]{3}{*}{ Woodlot } & & Fuelwood & Contraction wood & & & Others \\
\hline & Load/ha /year & & & & & \\
\hline & Price & & & & & \\
\hline \multirow[t]{3}{*}{ Livestock } & & Present & Sold & & & \\
\hline & Number & & & & & \\
\hline & Price & & & & & \\
\hline \multirow[t]{2}{*}{ Business } & Type & Trade & & & & \\
\hline & Income/ha/month & & & & & \\
\hline \multirow[t]{2}{*}{ Employment } & Type & Wage & Others & & & \\
\hline & Income/month & & & & & \\
\hline \multirow[t]{2}{*}{ Others } & Type & & & & & \\
\hline & Income/month & & & & & \\
\hline $\begin{array}{l}\text { Total income/year } \\
\text { in Birr }\end{array}$ & & & & & & \\
\hline
\end{tabular}


Appendix 3: Homegarden Household livelihoods contribution

1 What is your major source of income?

2 Which one of the following practice is your main source of household income? 1. Homegarden 2. Forest land 3. Farmland 4. if others specify

3 Why does your household maintain a homegarden? To: 1. spend time with my family 2. To produce food for my family 3. To generates additional income 4.For mental and physical relaxation 5. To beautify my home surrounding 6.Have no significant benefit 6 . Others, Specify

4 Please, list common plants you have been growing in your homegarden with their main uses:

\begin{tabular}{|l|l|l|l|l|}
\hline No. & Tree species & Plants primary use & Other Uses & Remark \\
\hline & & & & \\
\hline & & & & \\
\hline
\end{tabular}

9. Do you agree that the contribution of your garden products for family food and income generation is

\begin{tabular}{|l|l|l|}
\hline For family food & For income generation & Remark \\
\hline High & High & \\
\hline Medium & Medium & \\
\hline Low & Low & \\
\hline Never & Never & \\
\hline
\end{tabular}

10. Would you list your homegarden products with their major contribution?

Appendix 4: Check list for homegarden income calculation

\begin{tabular}{|c|c|c|c|c|c|c|c|c|c|c|}
\hline Sources & & \multicolumn{9}{|c|}{ Main products } \\
\hline \multirow[t]{3}{*}{ Homegarden } & & Coffee & Chat & Fruits & Vegetable & Spice & $\begin{array}{l}\text { Root \& } \\
\text { tuber }\end{array}$ & Fuelwood & $\begin{array}{l}\text { Contraction } \\
\text { wood }\end{array}$ & Others \\
\hline & $\begin{array}{l}\text { Yield in } \\
\mathrm{Kg} \text { or } \\
\text { kuntal/ha } \\
\text { /year }\end{array}$ & & & & & & & & & \\
\hline & Price & & & & & & & & & \\
\hline
\end{tabular}

13. What are the major benefits that you get from homegarden and how do you evaluate them as (1. High 2 . Medium 3. Low 4. None)?

\begin{tabular}{|l|l|l|}
\hline $\begin{array}{l}\text { How do you evaluate the benefit that you get from } \\
\text { homegarden? }\end{array}$ & Option & Remark \\
\hline Food & & \\
\hline Income & & \\
\hline Construction & & \\
\hline Fodder & & \\
\hline Shade & & \\
\hline Fuelwood & & \\
\hline Life fence & & \\
\hline
\end{tabular}

Thank You So Much for Your Cooperation

Respondent: sign

Appendix 5: Checklist for Focus Group Discussions (FGDs)

Introduction:

The Group Discussions is for the aim of the MSc thesis work to study "Contribution of Homegarden Agroforestry for Biodiversity Conservation and Local Livelihoods: The Case of Chora District, Southwestern Ethiopia" I would like to assure you that any ideas raised here are used only for this research. Your contribution has a vital role in the success of the study. Any of your opinions that will be included in this thesis report will not mention your name.

Thank you very much for your active participation essential ideas!

Instruction:

1. All members of the group should be equally participating.

2. Time allowed to one participation is __ minute in one turn. 
3. All ideas raised here are equally important for the study.

4. There are no wrong ideas, feel free to react to the issues raised.

5. All participants should listen properly when one of the members his/her idea

\section{Questions prepared for the discussion}

1. Understanding the components, plant diversity in homegarden Agroforestry practices and its socioeconomic contribution, Please briefly tell us about your experience in

2. In what ways are you more aware of the importance of the homegarden in plant biodiversity conservation? And would you describe the conservation roles of homegarden?

3. What is the contribution of homegarden for local community livelihood in your area?

4. Would you explain please, the contribution of homegarden to the local community in both income generation and family food production terms?

5. What type of plants do people in your area more interested to conserve in their garden?, Why?

6. Do you think are there criteria for gardeners to preserve plants in their garden?

7. Would you mention plants or tree varieties commonly observed in your area homegardens? What do you think is the most probable reason for the plants to be common in the homegardens of the area?

8. For what purpose do people, in this area practice homegarden mostly?

9. What are the purposes of trees component in homegarden?

10. Where do people in this area get forest products for their construction materials or firewood at most?

11. Do you think that is homegarden in your area effective enough for plant biodiversity conservation? If not why?

12. What is the most important constraint/problems for homegarden practices inefficiency for plant conservation in your area?

13. What options do you suggest in bringing sustainable plant biodiversity conservation in the area?

Appendix 6: Key Informants Interview

1. Please briefly tell us about your experience homegarden management and its contributions to the plant biodiversity conservation.

2. What do you think about homegardens and their contributions to the plant biodiversity in your areas?

3. What type of trees and crops that are commonly being managed in homegardens of this area and why?

4. How do you describe the contribution of the homegarden practice to YCFBR and plant biodiversity conservation in your areas?

5. Do you think homegardens have a role in household food security and income generation ?

6. Describe the value of homegarden to: 1. Livelihood and socioeconomic of the locals 2. plant biodiversity conservation and YCFBR

7. What do you think is the best alternative practice that may compensate products from YCFBR for surrounding community in favor of sustaining biodiversity conservation practices in this area?

8. What are the main problems locals are facing in relation to the diversifying of homegarden components? 